\title{
THE USE OF RENEWABLE ENERGY SOURCES IN URBAN PROTECTED CULTURAL-HISTORICAL AMBIENCES
}

\author{
A B S T R A C T
}

The aim of this study is a consideration of the possibilities for improving of energy efficiency in protected cultural and historical environments of Belgrade, by using renewable energy sources. The study analyzes the possibilities of integration of photovoltaic (PV) modules within the protected area of the Belgrade Fortress, which is a protected historical whole and cultural good of great importance. The work shows the possibilities of application of PV models, in order to provide the necessary electricity for the needs of the public lighting of Belgrade Fortress and the reduction of consumption of conventional energy sources. This paper aims to show the possibilities of the use of sustainable technologies in solving the problems of public lighting and environmental protection in the protected cultural-historical entities. The application of PV structures solves the problem of lighting in protected areas and provides energy from renewable sources. Systems for the use of renewable energy sources are becoming important architectural elements which have specific designed influences on the layout and form of the facility within which are implemented. The study included the specifics of the design and programmatic interventions in protected urban ambiences, through an analysis of shaped influences of photovoltaic panels to the protected objects and their contribution in the use of renewable energy sources. 


\section{INTRODUCTION}

This paper describes an energy efficient solution for providing electricity generation for lighting the Belgrade fortress during the year, by using the renewable energy sources. The production of electricity from renewable energy sources under specific circumstances, such as Belgrade Fortress requires that renewable energy source generate electricity without the noise and vibration, that the production is environmentally friendly, and that the whole system works autonomously. Need for maintenance of the system should be minimal and that the operating costs are as low as possible. ${ }^{1}$ The reason for this study was found in the facts that it is necessary theoretically and critically to approach to solving the problem of sustainability in protected cultural historical entities. The necessity of establishing a new urban and architectural models for solving energy, shaped and technological problems of protected whole gives the actuality to this topic. The application of renewable energy sources in order to support the sustainability of protected whole is directly related to the new technical solutions which contribute to environmental whole, reducing pollution and the fact that in the world for this purpose PV modules are applied (Fig. 1, 2). An example of a church in London on which are installed $\mathrm{PV}$ modules and with whose electricity production is reduced $\mathrm{CO}_{2}$ emission by $42 \%$, that contemporary approach to the protection of cultural property has to find solutions for the implementation of such systems.

The recommendations of individual conservators from England are that the PV modules are placed as mounting dismantling panels on the substructure. Conservationists acknowledge and recognize the negative impact of climate change on heritage objects which tend to deteriorate much faster in the changed climatic circumstances from their modern equivalents. Therefore, the use of alternative means for generating electricity and the reduction of $\mathrm{CO}_{2}$ emissions to a minimum in protected environmental units are the starting point is in a modern approach to the regeneration of existing heritage. ${ }^{2}$ The main problem in the realization of PV modules in the protected areas is that the solar panels themselves must be exposed to the sun, in order to be effective, and that because of that will probably be visible. The emergence of PV panels on the facilities can have a significant impact on its external appearance and therefore it is necessary to establish a balance between preserving heritage property and the public benefit from the effect of climate changes. The fact that there are already PV installations on protected objects shows that there is possible cooperation of renewable energy installations and facilities under the protection of cultural heritage. According to the recommendations of the English conservators. ${ }^{3}$ The application of PV modules in the protected zones is possible if the conditions that their use will not cause loss of particular interest protection are fulfilled; 
and that the visual impact of equipment is small; that the setting and installation of equipment will not cause the damage of historical materials; that the installed equipment will not lead to long-term impact on the facility.

The contemporary methodological approach in technical interventions on protected objects of architectural heritage is based on a complex scientific analysis of all elements that must be taken into consideration when making decisions. New purpose should not be of such nature that, to a certain extent, in the ethical sense degrades or offends the dignity and value of cultural monuments. ${ }^{4}$ From recently, the Vatican State is producing all its electricity from solar panel which are installed on their From almost the Vatican State virtually all its electricity produced from solar panels that are installed on their edifices. This very fact represents one of the biggest arguments for the careful placement of solar panels on the historical buildings mostly in zones that are not perceived from the street (Fig. 3).

The aim is to preserve the integrity and authenticity of cultural properties so actions that could lead to changes in form or appearance cannot be taken. ${ }^{5}$ In the town urban structure the Belgrade fortress has the status of cultural monuments - cultural property of extraordinary importance. The fortress has all the characteristics of the medieval fortified town customized to defense and security of the nobility and population settled within the village. The town has emerged and developed on the area of today's Belgrade fortress in the beginning as a Roman military camp, later as the Byzantine border fortress which has grown in the Serbian capital; a fortified town with a courtyard and civilian suburbs in early $15^{\text {th }}$ century; than in the early $16^{\text {th }}$ century it became a Turkish fortress with the established settlements; and in early $18^{\text {th }}$ century Austrian Baroque fortress. ${ }^{6}$ The Belgrade Fortress was declared for a cultural monument in 1946, just after WWII, when in the process of preservation and

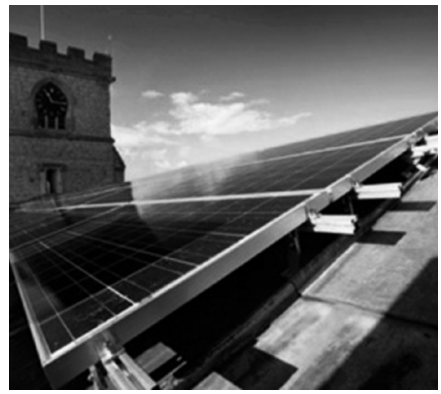

Figure 1. Photovoltaic panels on the roof of the nave at Wing All Saints, Buckinghamshire

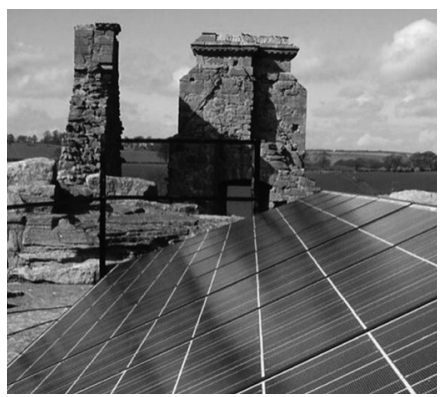

Figure 2. Photovoltaic panels in Crighton Castle Scotland

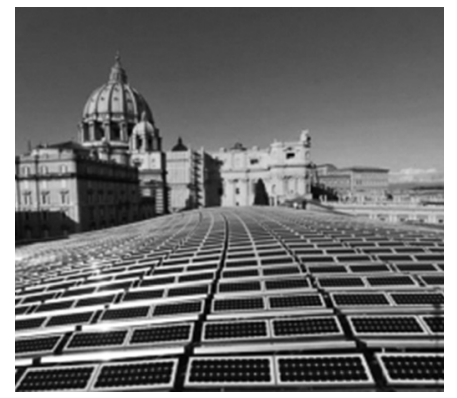

Figure 3. The solar panels, on the roof of the Nervi Hall will not interrupt the Vatican skyline 
revitalization it has started to be investigated methodically and systematically. It represents $\mathrm{s}$ a unique testimony of the past with preserved material remains from all past historical epochs, representing today a unique monumental unity of exceptional architectural, historical, cultural and geographical values. ${ }^{7}$

The Belgrade fortress has evolved in the extreme ridge of the most extended Avala, on a plateau above the confluence of great rivers, on embouchure Sava and the Danube, where the Pannonian basin is closest to the foothills on embouchure transition to hilly and mountainous Balkan massif. It has a north south direction of stretching. ${ }^{8}$ The fortress has a heterogeneous structure of an approximate surface of 80 hectares. In the period from the end of $19^{\text {th }}$ century after the liberation from Ottoman reign, begins the process of planning and arrangement of the fortress surroundings, which still had a military purpose, and the formation of the park on the slopes of the river Sava and toward the civil settlement. ${ }^{9}$

Today's appearance of the Belgrade Fortress as a the fortification whole was formed during the two millenniums. Construction, demolition and reconstruction of the Belgrade fortress ramparts reflects the ups and downs of Belgrade, as well as the great importance of its position in the past. Today, the protected area of the Belgrade Fortress (Fig. 4, 5), in the spatial and functional sense; makes the complex unit encompassing fortress ramparts and buildings within them, Kalemegdan park and the coastal strip of Sava (Beton Hall on the Sava pier) and Danube (with a sports center Gale Muškatirović and other new facilities). ${ }^{10}$

The analysis presented in this paper is hypothetical and aims to demonstrate the possibilities of architectural and energy utilization of active solar systems in Belgrade climatic conditions on the example of Belgrade fortress as an immovable cultural property of exceptional importance. The work methodology is presented through the analysis of climatic characteristics of Belgrade, analysis

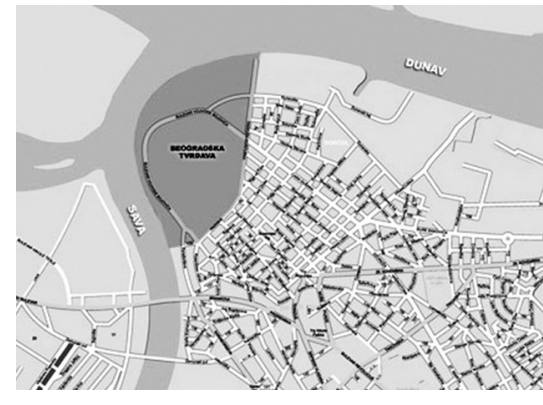

Figure 4. Protected zone of the Belgrade Fortress

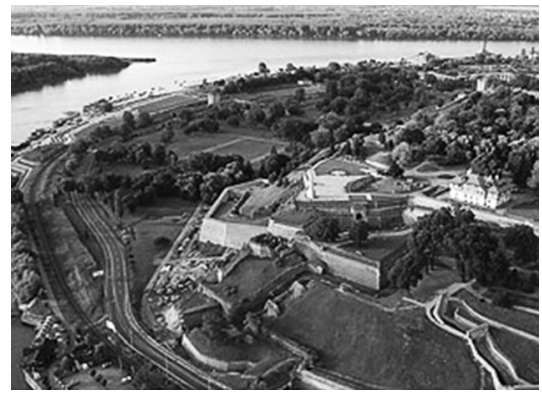

Figure 5. Aerial view of the Belgrade Fortress 
of the current electricity consumption for lighting of the Belgrade Fortress, the ability to integrate PV modules into protected cultural - historical environments, analysis of the obtained amount of electricity, reduction of $\mathrm{CO}_{2}$ emissions. The obtained results were analyzed relatively. Energy efficiency is treated through the consumption of electricity to power the existing lighting using the standard light sources - high sodium pressure.

\section{RENEWABLE ENERGY SOURCES}

Renewable energy sources and their use are closely connected with sustainable development. In order to achieve sustainable development, an important role plays the increasing of energy efficiency of processes which use renewable sources of energy. Solar energy is a renewable and unlimited source of energy from which, directly or indirectly, originates the largest part of other sources of energy on earth. Active use of solar energy as an energy source involves the conversion of solar radiation into electricity. The photovoltaic receivers are devices which are used for the direct conversion of solar energy into electricity with relatively low level of useful effect. ${ }^{11}$ Very thin crystal silicon plates with the admixture of arsenic of semiconductor PN compound exposed to light radiation of the sun, act as a semiconductor circuit and power source. Photovoltaic cells have no moving parts, have a long service life and require a minimal maintenance. Systems which use a renewable energy sources have become important architectural elements, but their shape and size leads to changes in the appearance and shape of objects on which they are implemented. Project designing of these elements and such a conception of the use of renewable energy sources aims to improve and super integration of fundamental human needs for energy by observing them as a meta systemic transition towards a completely new possibilities of architecture, society and technology.

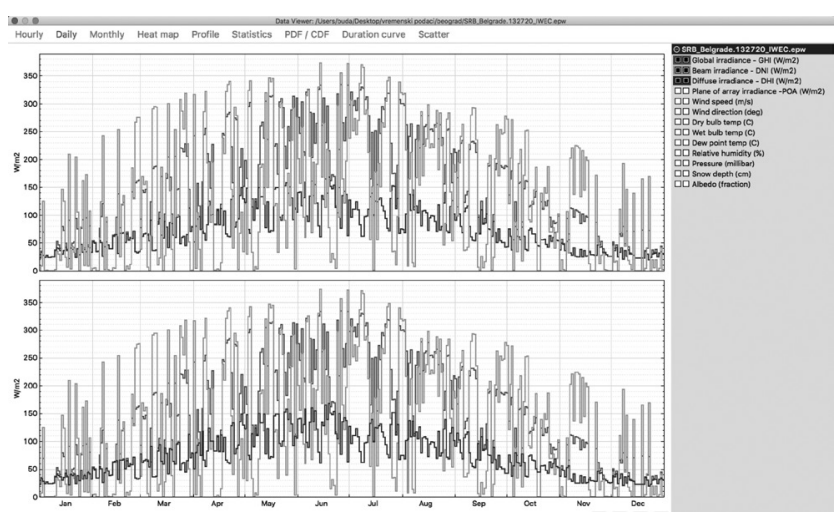

Figure 6. Preview of daily irridiation to Belgrade

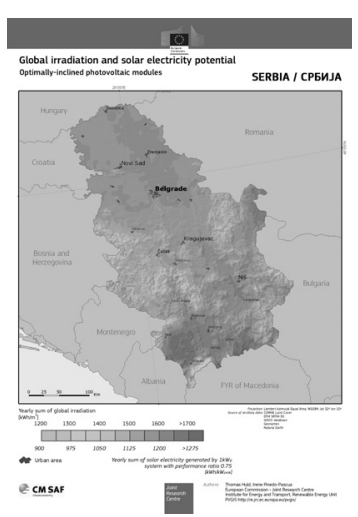

Figure 7. Preview of total annual insolation for Serbia 
A contemporary approach to the protection and revitalization of cultural monuments allows the use of elements that contain certain characteristics, qualitative values and indicators energy potentials of such wholes. ${ }^{12}$ The use of PV modules represents an interactive element with a direct impact on the energy balance of a building or some environment. This research is based on an experimental approach which is used for assessing the effect of the use of photovoltaic cells on the energy performance of public lighting in the Belgrade fortress with predictions that their implementation would affect the reduction in consumption of conventional energy sources. Solar energy is an inexhaustible source of energy compared to traditional energy sources for whose use are not required any special geological researches. By using solar energy for electricity production, it is not contaminating the environment of man, waste substances are not created. ${ }^{13}$ Solar energy is a completely free energy source and allows the production of electricity at the point where it is consumed. The photovoltaic systems are an integrated set of PV modules and other components, designed so that the primary solar energy directly converts into final electrical energy that ensures operation of a certain number of consumers. ${ }^{14}$

The application of photovoltaic cells in a protected cultural whole would be very attractive in terms of representation of such a facility to the general public. In the world can be noticed an increase in the number of cultural and scientific institutions that strive to reduce the overall amount of electricity taken from the network, and this is almost always achieved by local production from the photovoltaic cells.

Renewable energy sources are gaining more and more attention as energy sources of the future. Renewable energy sources are still not competitive with conventional sources, especially because the conventional sources still do not charge external costs of production and the system of green certificates has not yet been developed in many countries. In order to encourage the development of renewable energy sources many countries have developed a mechanism for subsidizing those sources of energy. ${ }^{15}$ Photovoltaic conversion of solar radiation is based on the photoelectric effect on the semiconductor material and the capacity of PN junction rectifier. Due to the absorption of solar radiation in the PN junction are occurring the couples electron - hole. As a consequence of the movement of electrons and holes at the ends of the solar cell, there is a potential difference or the voltage. ${ }^{16}$ The criteria for the evaluation of the aesthetic quality of photovoltaic systems are: the naturalness of setting, architectural impression, composition of colors and materials, the harmony of solutions, match in the context of the object and design innovation. The power of the solar radiation on the Earth's surface (Fig. 6) depends on several factors: the geographical 
latitude, cloudiness, season, time of day, the shading. When taking into account all these factors a realistic picture of the average annual insolation $\left(\mathrm{kWh} / \mathrm{m}^{2}\right)$ for Serbia. Serbia has 267 sunny days per year and every square meter of the Earth's surface receives 1000 hours of solar energy. In Serbia, there is a potential for the production of electricity using solar energy (Fig. 7), because the sunshine is 20-30 percent higher than the European average. The potential of solar energy represents $16.7 \%$ of total usable potential of renewable energy sources in Serbia. The energy potential of solar radiation is about $30 \%$ higher in Serbia than in Central Europe and the intensity of solar radiation is among the highest in Europe. The average intensity of solar radiation on the territory of the Republic of Serbia ranges between $1.1 \mathrm{kWh} / \mathrm{m}^{2} /$ day in the north and 1.7 $\mathrm{kWh} / \mathrm{m}^{2} /$ day in the south (during January), and from 5.9 to $6.6 \mathrm{kWh} / \mathrm{m}^{2} /$ day (during July). Belgrade has a moderate continental climate. Winters are cold and summers are dry and warm. The average annual air temperature in Belgrade is $11.9^{\circ} \mathrm{C}$. There is an average of 2096 hours of sunshine per year (which makes 45.48 percent of the potential/possible insolation). The highest insolation of approximately 10 hours per day is in July and August, while in December and January are the cloudiest, with insolation of 2 to 2.3 hours per day (Fig. 1). The average annual number of cloudy days is 103.8 , most of them are during the winter. The average number of clear days per year is the 67 .

\section{LIGHTING OF THE BELGRADE FORTRESS}

Lighting of the Belgrade Fortress using conventional sources of electricity is very expensive and has a negative impact on the environment, which is why this work is examining it. Illumination is provided by high-pressure lamps of sodium lighting sources, of different installed capacity. It is characterized by high luminous efficiency and a limited spectrum of radiation reaching the

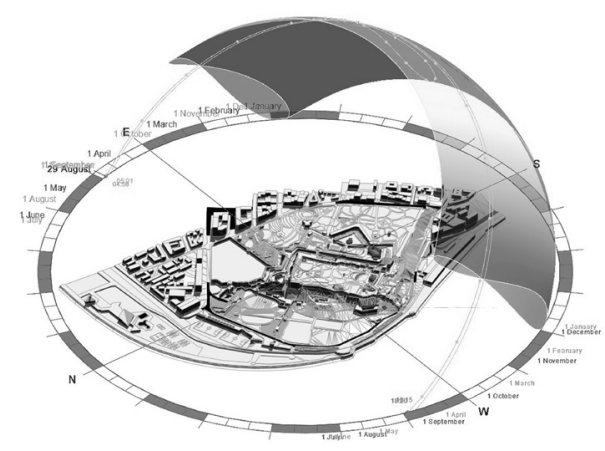

Figure 8. Annual Solar paths diagram (b) Sun's azimuth at Belgrade (Lat. $44.40 \mathrm{~N}$, long. 20.40E, alt. $76 \mathrm{~m}$ )

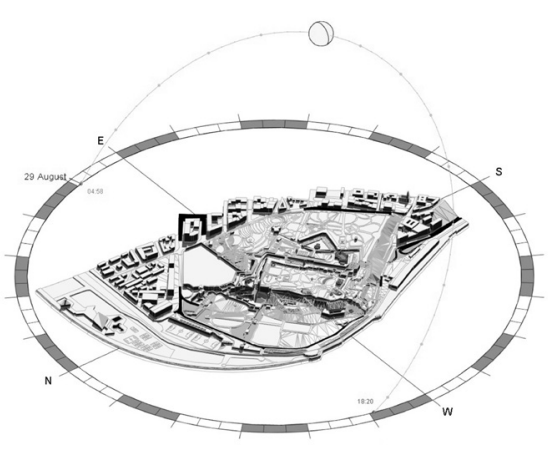

Figure 9. Sun's azimuth at Belgrade (Lat. $44.40 \mathrm{~N}$, long. $20.40 \mathrm{E}$, alt. $76 \mathrm{~m}$ ) 
highest level in a yellow-orange color. These light sources are typically used for the needs of public lighting in Serbia. They consume large amounts of electricity, which is why in this paper is researched how to provide the necessary energy from renewable sources. Belgrade fort also represents a good location for setting up photovoltaic cells. Preferred is orientation towards the sides of the world (Figure 8,9), a large surface of the walls - ramparts to set up the installation of PV modules. The desirability of the fortress position is reflected in the fact that, the places where it is possible to set the PV modules are not surrounded by high-rise buildings. By visual observation in different parts of the day and year, it was observed that it comes to no occurrence of shadows due to objects within the Belgrade fortress, so that there is no decline in the efficiency of the module. The realization of this research would have an impact on the better voltage circumstances in the central part of the city and to some extent would unloaded the capacity of the distribution network. Central city zones are good places for locating solar panels in terms of infrastructure. Built on a place like this, this solar power plant will be visible Though it does not belong to the technical benefits, it will increase people's awareness of ecology and environmental protection.

\section{ANALYSIS OF POWER CONSUMPTION FOR ILLUMINATING}

This study has attempted to find a possibility of reducing the consumption of conventional energy sources for the needs of public lighting and illumination of the Belgrade Fortress with electricity obtained from renewable sources of energy, by applying photovoltaic modules. For the calculation is of paramount importance to establish the solar potential on target site. Budget analysis of the solar potential on location of the Belgrade fortress (N44.817, E20.457) was carried out in two ways:

1. We used the data measuring horizontal irradiation for Belgrade, Serbia, during 2015.

2. We used a free online version of the PVGIS PV syst V6.47 that use satellite data for the calculation of the solar potential.

Daily consumption of electricity for lighting of the Belgrade Fortress varies.

The total length of daylight, illumination for Belgrade according to data from the Hydrometeorological Institute is 4464.83 hours per year. The minimum duration of a day in the month of December is 270.56 hours, and the highest is in July 473.42 hours. According to the current calendar of ignition and shutdown of public lighting for the city of Belgrade (updated 16.10.2011. y.) The total number of working hours of public lighting in Belgrade is 4148.23 hours per year (Fig. 10, 11). The minimum number of working hours of illumination in 
the month of June is 222.30 hours, and the highest is in December and amounts to 467.45 hours. The indicated number of working hours of illumination is directly related to the length of daylight for Belgrade. (Table 1)

TABLE I: Total length of daylight for Belgrade and total number of operating hours of public lighting by month

\begin{tabular}{|c|c|c|c|c|c|}
\hline M & $\begin{array}{c}\text { LENGTH OF } \\
\text { DAYLIGHT FOR } \\
\text { BELGRADE }\end{array}$ & $\begin{array}{l}\text { NUMBER OF } \\
\text { OPERAT ING } \\
\text { HOURS OF } \\
\text { PUBLIC } \\
\text { LIGHT ING }\end{array}$ & M & $\begin{array}{c}\text { LENGTH OF } \\
\text { DAYLIGHT FOR } \\
\text { BELGRADE }\end{array}$ & $\begin{array}{l}\text { NUMBER OF } \\
\text { OPERATING } \\
\text { HOURS OF } \\
\text { PUBLIC } \\
\text { LIGHTING }\end{array}$ \\
\hline 1 & 282.32 & 452.00 & 7 & 473.42 & 248.00 \\
\hline 2 & 291.44 & 385.15 & 8 & 439.93 & 286.45 \\
\hline 3 & 362.99 & 364.15 & 9 & 376.96 & 327.00 \\
\hline 4 & 403.52 & 310.13 & 10 & 343.14 & 392.45 \\
\hline 5 & 455.08 & 271.15 & 11 & 294.07 & 422.00 \\
\hline \multirow[t]{2}{*}{6} & 471.40 & 222.30 & 12 & 270.56 & 467.45 \\
\hline & & \multicolumn{2}{|c|}{ TOTAL } & 4464.8 & 4148.23 \\
\hline
\end{tabular}

Average time available for electricity production, TPV, during the three summer months (June, July and August) in Serbia is about $6.6 \mathrm{~h}$. During the three winter months (December, January and February) is only about $1.06 \mathrm{~h}$, so $1.06 \mathrm{t} \leq \mathrm{TPV}$ $\leq 6.6 \mathrm{~h}$. The total annual number of hours of insolation in Serbia in 2012 is $^{17}$ :

$$
T_{A}=\frac{\sum_{i=1}^{12} E_{i}}{P_{P V}}=1.442,8 h
$$

With the analysis has been taken into calculation the consumption of electricity for the needs of public lightening according to the data of JKP Public lightening Belgrade. The existing light bulbs were averaged installed capacity of $181 \mathrm{~W} /$ pcs. Number of lamps in the analyzed section is 815 units. different installed power and type of lamp (Table 2).

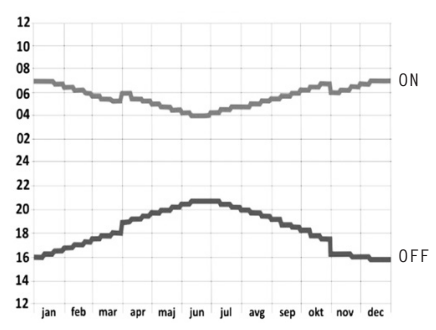

Figure 10. Number of operating hours of public lighting for Belgrade fortress by month

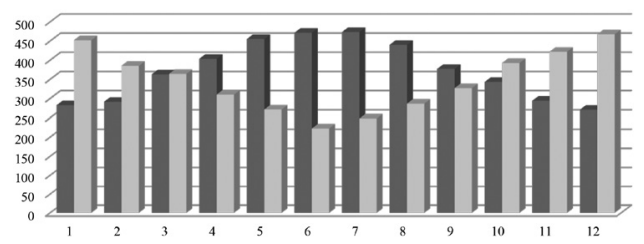

Figure 11. Comparison of total length of daylight for Belgrade and total number of operating hours of public lighting 
TABLE I I : Presentation of existing lighting and electricity necessary for the work of public lighting in Belgrade fortress

\begin{tabular}{|c|c|c|c|c|c|}
\hline $\begin{array}{c}\text { CODE OF LIGHT } \\
\text { BULBS }\end{array}$ & SOURCE TYPE & TYPE OF BULB & PCS & $\begin{array}{c}\text { POWER OF } \\
\text { LIGHT } \\
\text { BULBS } \\
\text { KW }\end{array}$ & TOTAL \\
\hline $\begin{array}{l}\text { RT } 3 \mathrm{NB} / 71 / 400 \text { with } \\
\text { protection network }\end{array}$ & high pressure sodium & SON-T PLUS 400W & 68 & 0.4 & 27.2 \\
\hline $\begin{array}{l}\text { RT 3NB/21/250 with } \\
\text { imbus screws }\end{array}$ & high pressure sodium & SON-T PLUS 250W & 59 & 0.25 & 14.75 \\
\hline $\begin{array}{l}\text { RT3NB/71/150 with } \\
\text { imbus screws }\end{array}$ & high pressure sodium & SON-T PLUS $150 \mathrm{~W}$ & 3 & 0.15 & 0.45 \\
\hline $\mathrm{RT} 2 \mathrm{NB} / 271 / 70$ & high pressure sodium & SON-T PLUS 70W & 16 & 0.07 & 1.12 \\
\hline $\mathrm{RD} 4 \mathrm{~N} / 1103 / 1000$ & high pressure sodium & SON-T PLUS $1000 \mathrm{~W}$ & 1 & 1 & 1.00 \\
\hline $\mathrm{RD} 3 \mathrm{~N} / 1216 / 400$ & high pressure sodium & SON-T PLUS 400W & 5 & 0.4 & 2.00 \\
\hline $\mathrm{RD} 3 \mathrm{~N} / 83 / 250$ & high pressure sodium & SON-T PLUS 250W & 95 & 0.25 & 23.75 \\
\hline $\mathrm{RD} 3 \mathrm{I} / 83 / 250$ & metal halogen & MH-250W & 50 & 0.25 & 12.5 \\
\hline $\mathrm{RD} 3 \mathrm{I} / 1277 / 250$ & metal halogen & MH-250W & 1 & 0.25 & 0.25 \\
\hline $\begin{array}{l}\mathrm{RD} 2 \mathrm{~N} / 1366 / 150 \text { with } \\
\text { protection network }\end{array}$ & high pressure sodium & SON-T PLUS $150 \mathrm{~W}$ & 34 & 0,15 & 5,10 \\
\hline $\begin{array}{l}\mathrm{RD} 2 \mathrm{~N} / 1453 / 150 \text { with } \\
\text { protection network }\end{array}$ & high pressure sodium & SON-T PLUS $150 \mathrm{~W}$ & 264 & 0,15 & 39,6 \\
\hline $\begin{array}{l}\mathrm{RD} 2 \mathrm{~V} / 1366 / 150 \text { with } \\
\text { protection network }\end{array}$ & metal halogen & MH-150W & 36 & 0.15 & 5.4 \\
\hline $\begin{array}{l}\mathrm{RD} 2 \mathrm{I} / 1453 / 150 \text { with } \\
\text { protection network }\end{array}$ & metal halogen & MH-150W & 3 & 0.15 & 0.45 \\
\hline $\begin{array}{l}\mathrm{RD} 2 \mathrm{~N} / 1364 / 70 \text { with } \\
\text { protection network }\end{array}$ & high pressure sodium & SON-T 70W & 9 & 0.07 & 0.63 \\
\hline FOCAL-N 1691/70 & high pressure sodium & SON-T 70W & 58 & 0.07 & 4.06 \\
\hline FOCAL-I 1691/150 & metal halogen & MH-150W & 1 & 0.15 & 0.15 \\
\hline TERRA-I / 83-2/150 & metal halogen & MH-150W & 11 & 0.15 & 1.65 \\
\hline TERRA-N / 83-2/70 & high pressure sodium & SON-T 70W & 36 & 0.07 & 2.52 \\
\hline CORUS-N / 1530/70 & high pressure sodium & SON-T 70W & 62 & 0.07 & 4.34 \\
\hline \multirow[t]{2}{*}{ CORUS-I / 1530/150 } & metal halogen & MH-150W & 3 & 0.15 & 0.45 \\
\hline & & TOTAL & 815 & 4.35 & 147.37 \\
\hline
\end{tabular}
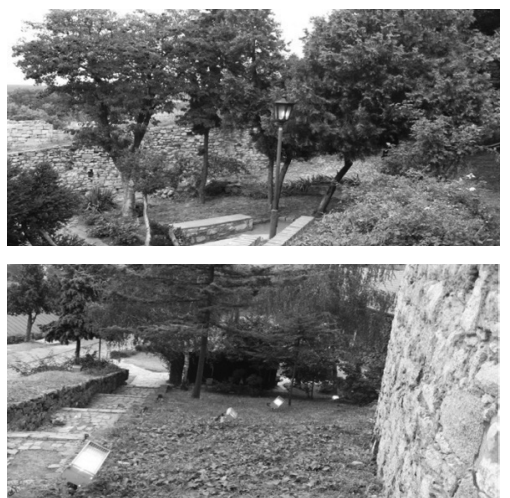

Figure 12. Preview of the existing light sources at the Belgrade Fortress: a) RT3NB / 71/400 with protection NETWORK, b) RT2NB / 271/70
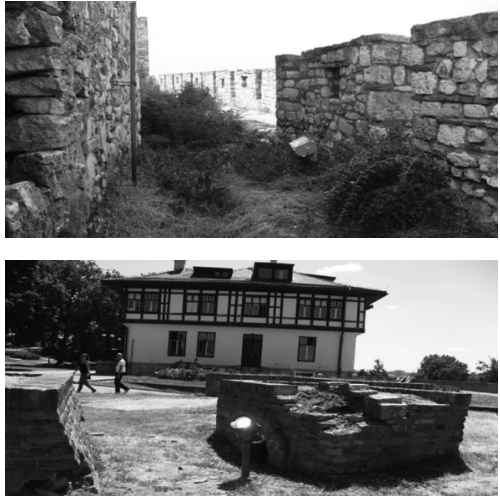

Figure 13. Preview of the existing light sources at the Belgrade Fortress: a) RD 3I/1277/250, b) TERRA-I/83-2/150 
The total installed capacity for the needs of public lighting in Belgrade fortress is $147.37 \mathrm{~kW}$ (Figure 12, 13, 14). The required quantity of electricity for the operation of this type of illumination depending on the number of working hours of public lighting is $611324.66 \mathrm{kWh}$ per year. The largest electricity consumption is in December $68888.11 \mathrm{kWh}$, and the lowest is in June 32760.35 $\mathrm{kWh}$. All of the above energy is provided from conventional energy sources (Table 3).

TABLE II : Presentation of existing lighting and electricity necessary for operation of public lighting in Belgrade fortress

\begin{tabular}{lcccccc}
\hline & $\begin{array}{c}\text { HOURS OF } \\
\text { WORK OF } \\
\text { LAMPS }\end{array}$ & $\begin{array}{c}\text { NUMBER } \\
\text { DAYS }\end{array}$ & $\begin{array}{c}\text { NUMBER OF } \\
\text { LAMPS }\end{array}$ & $\begin{array}{c}\text { POWER } \\
\text { LAMPS }\end{array}$ & $\begin{array}{c}\text { KW } \\
\text { PONTALLE }\end{array}$ & $\begin{array}{c}\text { TOTAL MONTHLY } \\
\text { CONSUMPTION } \\
\text { KW }\end{array}$ \\
\hline January & 452 & 31 & 815 & 0.181 & 147.37 & 66611.24 \\
February & 385.15 & 28 & 815 & 0.181 & 147.37 & 56759.56 \\
March & 364.15 & 31 & 815 & 0.181 & 147.37 & 53664.79 \\
Apri1 & 310.13 & 30 & 815 & 0.181 & 147.37 & 45703.86 \\
May & 271.15 & 31 & 815 & 0.181 & 147.37 & 39959.38 \\
June & 222.3 & 30 & 815 & 0.181 & 147.37 & 32760.35 \\
Juty & 248 & 31 & 815 & 0.181 & 147.37 & 36547.76 \\
August & 286.45 & 31 & 815 & 0.181 & 147.37 & 42214.14 \\
September & 327 & 30 & 815 & 0.181 & 147.37 & 48189.99 \\
October & 392.45 & 31 & 815 & 0.181 & 147.37 & 57835.36 \\
November & 422 & 30 & 815 & 0.181 & 147.37 & 62190.14 \\
December & 467.45 & 31 & 815 & 0.181 & 147.37 & 68888.11 \\
\hline T0TAL & 4148.23 & 365 & 9780 & 2.172 & 1768.44 & 611324.66 \\
\hline
\end{tabular}

According to the current tariff system, the price of electricity is $6.8 \mathrm{RSD} / \mathrm{kWh}$, so that the total annual amount of the price of electricity for lighting of the Belgrade Fortress is

$611324.66 \mathrm{kWh} \times 6.8 \mathrm{RSD} / \mathrm{kWh}=4157007.65$ or 33524.26 Euros $^{18}$

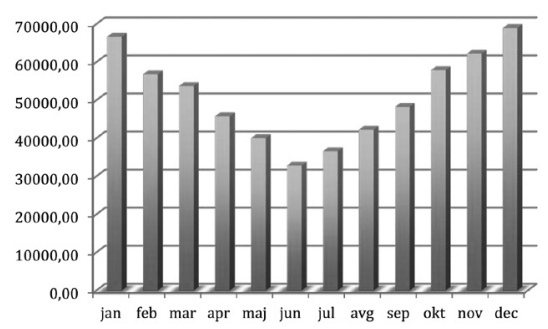

Figure 14. Consumption kWh of electricity of existing lighting by month

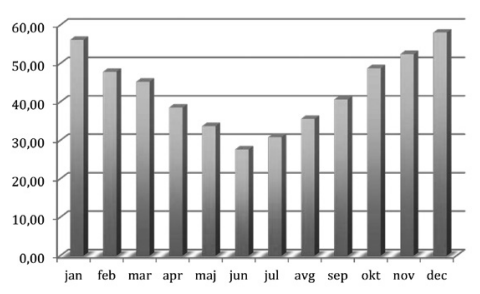

Figure 15. Preview of $\mathrm{CO}_{2}$ emissions of the existing lighting by month 
The existing lights are modern, of excellent photometric characteristics and a high degree of mechanical and electrical protection with a secure longexploitation service life.

In the Belgrade Fortress, as well as in all major urban areas maintenance of installations of public lighting represents a major problem - because of the huge number of lamps it is almost impossible to constant control correctness of each luminarie. Detection of fault (determining the type and fault location) requires a lot of time and engagement of many people, which increases the costs of maintaining the public lighting system and automatically reduces its effectiveness. The greater demands on the quality of lighting as well as requirements for greater savings of resources daily increase the need for the implementation of remote control system. ${ }^{19}$

\section{EMISSION OF $\mathrm{CO}_{2}$}

According to the current data for Serbia that for the production of $1 \mathrm{kWh}$ of electricity by using conventional sources of energy in the atmosphere releases $842 \mathrm{~g}$ of $\mathrm{CO}_{2}$. By analyzing the input data we have obtained that the total $\mathrm{CO}_{2}$ emissions is $514.74 \mathrm{t}$ /year. (Fig. 15, 16). As stated earlier generation of electricity from renewable energy sources have no $\mathrm{CO}_{2}$ emissions and no pollution of the environment.

TABLE IV: Preview of $\mathrm{CO}_{2}$ emissions of the existing lighting by month

\begin{tabular}{lcccc}
\hline & $\begin{array}{c}\text { Hours of work of } \\
\text { lamps }\end{array}$ & $\begin{array}{c}\text { Total monthly } \\
\text { consumption kW }\end{array}$ & Emission of CO2 t & $\begin{array}{c}\text { Total emission of } \mathrm{CO}_{2} \\
\text { per months }\end{array}$ \\
\hline January & 452 & 66611.24 & 0.000842 & 56.09 \\
February & 385.15 & 56759.56 & 0.000842 & 47.79 \\
March & 364.15 & 53664.79 & 0.000842 & 45.19 \\
April & 310.13 & 45703.86 & 0.000842 & 38.48 \\
May & 271.15 & 39959.38 & 0.000842 & 33.65 \\
June & 222.3 & 32760.35 & 0.000842 & 27.58 \\
July & 248 & 36547.76 & 0.000842 & 30.77 \\
August & 286.45 & 42214.14 & 0.000842 & 35.54 \\
September & 327 & 48189.99 & 0.000842 & 40.58 \\
October & 392.45 & 57835.36 & 0.000842 & 48.70 \\
November & 422 & 62190.14 & 0.000842 & 52.36 \\
December & 467.45 & 68888.11 & 0.000842 & 58.00 \\
\hline & 4148.23 & 611324.66 & 0.010104 & 514.74 \\
\hline
\end{tabular}




\section{ANALYSIS OF DIFFERENT VARIANTS OF INTEGRATION OF PV MODULES}

For a comparative analysis of the integration of photovoltaic modules (Fig. 16), monthly and annual production of electrical energy necessary for illuminating the Belgrade fortress three variants are analyzed. It is evident that the different degree to which the installed photovoltaic modules give different results of total annual electricity production.

The energy of solar radiation is more than sufficient to meet all the needs for energy in the world. The energy of solar radiation that reaches the earth's surface and which potentially can be used amounts to about 190 million terawatt hours per year. This energy is about 170 times greater than the total energy reserves of coal, oil and gas in the world. About $37 \%$ of world energy demand is satisfied with production of electrical energy which in 2008 was amounted to 17000 TWh. The Belgrade fortress is not surrounded by tall buildings so that at no time during the year does not create a shadow on the roof of the faculty, so that the shadow factor at any point does not have to be considered.

Belgrade fortress is oriented $30^{\circ}$ to the southwest. It is planned that the solar panels are installed on the wall surfaces of the ramparts of the fortress, which also have the most optimal azimuthal angle. For analysis were adopted three variants of position of photovoltaic modules:

- Variant 1: PV modules in vertical wall, non-transparent, polycrystalline, ventilated angle of $0^{\circ}$.

- Variant 2: PV modules in vertical wall non-transparent, polycrystalline, ventilated angle of setting $5^{\circ}$

- Variant 3: PV modules within vertical wall, non-transparent, polycrystalline, ventilated angle of setting $30^{\circ}$

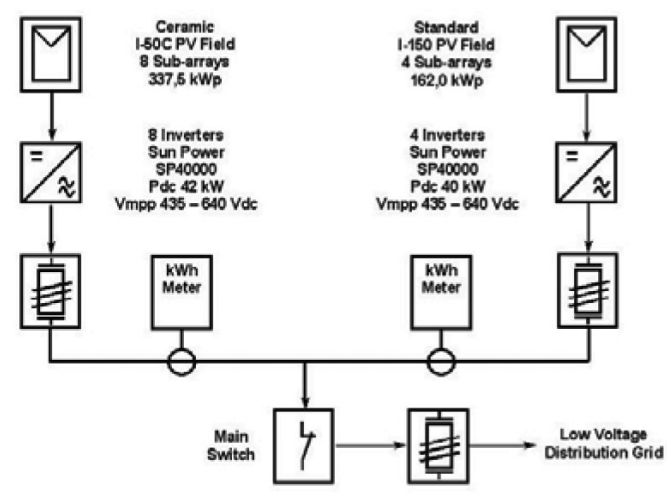

Figure 16. Simplified electrical scheme of the PV system 
A very important factor in the calculation of the necessary PV modules for electricity generation is a calculation of the solar potential for the relevant location. Calculation of the solar potential on panels is made where as entrance data, we have the latitude, the azimuth angle and tilt angle of the panel. In the first case the angle of tilt angle is $0^{\circ}$. As a result of the calculation we get all three components of the mean daily irradiation. (Table 5, Figure 17).

TABLE V: Tabular presentation of average daily solar irradiance potential for PV modules mounted at an angle of $0^{\circ}-$ Variant 1

\begin{tabular}{|c|c|c|c|c|c|c|c|c|c|c|}
\hline MONTH & $\mathrm{HH}$ & HOPT & $H(0)$ & DNI & IOPT & $\mathrm{TL}$ & $D / G$ & TD & $\mathrm{T} 24 \mathrm{H}$ & NDD \\
\hline Jan & 1180 & 1740 & 1180 & 1220 & 60 & 2 & 0.67 & 2.2 & 0.6 & 513 \\
\hline Feb & 1930 & 2660 & 1930 & 1920 & 54 & 2.3 & 0.6 & 2.8 & 1.3 & 386 \\
\hline Mar & 3640 & 4560 & 3640 & 3430 & 44 & 2.6 & 0.52 & 9.1 & 7.1 & 302 \\
\hline Apr & 4850 & 5380 & 4850 & 4530 & 30 & 3 & 0.44 & 14.9 & 12.8 & 99 \\
\hline May & 5770 & 5790 & 5770 & 5100 & 17 & 3.6 & 0.42 & 19.8 & 17.8 & 24 \\
\hline June & 6330 & 6040 & 6330 & 5610 & 11 & 3.5 & 0.4 & 23 & 21.4 & 4 \\
\hline JuTy & 6500 & 6350 & 6500 & 6310 & 15 & 3.3 & 0.35 & 25.1 & 23.5 & 0 \\
\hline Aug & 5710 & 6160 & 5710 & 6090 & 26 & 3.4 & 0.33 & 25.1 & 23.1 & 11 \\
\hline Sep & 4050 & 4960 & 4050 & 4310 & 41 & 3.4 & 0.42 & 19.9 & 17.9 & 63 \\
\hline $0 c t$ & 2810 & 3990 & 2810 & 3350 & 54 & 2.7 & 0.47 & 15.2 & 13 & 243 \\
\hline Nov & 1570 & 2490 & 1570 & 2030 & 62 & 2.1 & 0.56 & 9.8 & 8 & 408 \\
\hline Dec & 963 & 1450 & 963 & 1020 & 61 & 2 & 0.69 & 3.8 & 2.2 & 523 \\
\hline YEAR & 3790 & 4310 & 3790 & 3750 & 34 & 2.9 & 0.43 & 14.2 & 12.4 & 2576 \\
\hline \multicolumn{11}{|c|}{$\begin{array}{l}\text { Hh: Medium horizontal insolation per unit area }\left(\mathrm{Wh} / \mathrm{m}^{2} / \text { day); Hopt: Medium insolation for optimal tilt angle }\left(\mathrm{Wh} / \mathrm{m}^{2} / \text { day); } \mathrm{H}(4) \text {, }\right.\right. \\
H \text { (29): Medium insolation for angles } 4.85 \text { and } 29.1\left(\mathrm{Wh} / \mathrm{m}^{2} / \text { day); DNI: The direct component of solar insolation }\left(\mathrm{Wh} / \mathrm{m}^{2} / \text { day }\right)\right. \\
\text { Iopt Optimal angles (in degrees); D/G: Relationship of diffuse and total solar radiation; TD: Average daily temperature in } \\
\text { degrees Celsius (during daylight); T24h: Medium daily temperature during all } 24 \text { hours in degrees Celsius }\end{array}$} \\
\hline
\end{tabular}

Based on these data (Table IV, Fig. 17) can draw conclusions about the solar potential for tilt $0^{\circ}$ :

1. The average annual irradiation: $144.87 \mathrm{~W} / \mathrm{m}^{2}$

2. The total annual insolation for $2009: 1321.60 \mathrm{kWh} / \mathrm{m}^{2}$

3. The direct component of the annual insolation for $2009: 679.43 \mathrm{kWh} / \mathrm{m}^{2}$

4. The diffuse component of the annual insolation for 2009: 642.17 $\mathrm{kWh} / \mathrm{m}^{2}$

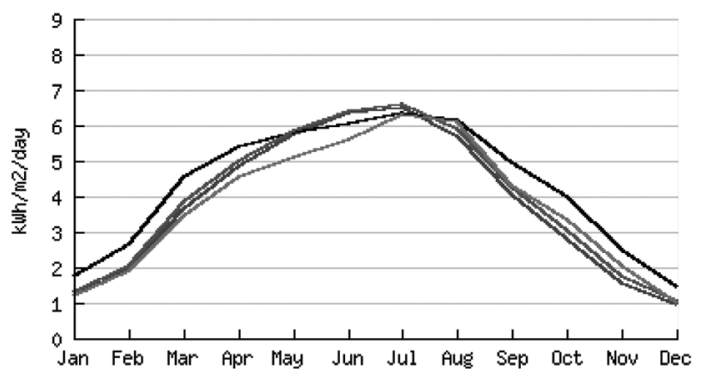

$44^{\circ} 49^{\prime} 12^{\prime \prime N o r t h, ~} 20^{\circ} 27^{\prime} 3^{\prime \prime}$ East 
TABLE VI: Tabular presentation of average daily solar irradiance potential for PV modules mounted at an angle of $5^{\circ}$ - Variant 2

\begin{tabular}{|c|c|c|c|c|c|c|c|c|c|c|}
\hline MONTH & $\mathrm{HH}$ & HOPT & $\mathrm{H}(30)$ & DNI & IOPT & $\mathrm{TL}$ & $\mathrm{D} / \mathrm{G}$ & $\mathrm{TD}$ & $\mathrm{T} 24 \mathrm{H}$ & NDD \\
\hline JAN & 1180 & 1740 & 1690 & 1220 & 60 & 2 & 0.67 & 2.2 & 0.6 & 513 \\
\hline FEB & 1930 & 2660 & 2610 & 1920 & 54 & 2.3 & 0.6 & 2.8 & 1.3 & 386 \\
\hline MAR & 3640 & 4560 & 4510 & 3430 & 44 & 2.6 & 0.52 & 9.1 & 7.1 & 302 \\
\hline APR & 4850 & 5380 & 5390 & 4530 & 30 & 3 & 0.44 & 14.9 & 12.8 & 99 \\
\hline MAY & 5770 & 5790 & 5860 & 5100 & 17 & 3.6 & 0.42 & 19.8 & 17.8 & 24 \\
\hline JUN & 6330 & 6040 & 6150 & 5610 & 11 & 3.5 & 0.4 & 23 & 21.4 & 4 \\
\hline JUL & 6500 & 6350 & 6450 & 6310 & 15 & 3.3 & 0.35 & 25.1 & 23.5 & 0 \\
\hline AUG & 5710 & 6160 & 6200 & 6090 & 26 & 3.4 & 0.33 & 25.1 & 23.1 & 11 \\
\hline SEP & 4050 & 4960 & 4920 & 4310 & 41 & 3.4 & 0.42 & 19.9 & 17.9 & 63 \\
\hline OCT & 2810 & 3990 & 3910 & 3350 & 54 & 2.7 & 0.47 & 15.2 & 13 & 243 \\
\hline NOV & 1570 & 2490 & 2410 & 2030 & 62 & 2.1 & 0.56 & 9.8 & 8 & 408 \\
\hline $\mathrm{DEC}$ & 963 & 1450 & 1410 & 1020 & 61 & 2 & 0.69 & 3.8 & 2.2 & 523 \\
\hline YEAR & 3790 & 4310 & 4300 & 3750 & 34 & 2.9 & 0.43 & 14.2 & 12.4 & 2576 \\
\hline
\end{tabular}

Based on these data (Table 6, Fig. 18) can draw conclusions about the solar potential of the tilt $5^{\circ}$ :

1. The average annual irradiation: $160833 \mathrm{~W} / \mathrm{m}^{2}$

2. The total annual insolation for 2009: $1408.9 \mathrm{kWh} / \mathrm{m}^{2}$

3. Direct component of the annual insolation for 2009: $788984 \mathrm{kWh} / \mathrm{m}^{2}$

4. The diffuse component of the annual insolation for 2009: 619916 $\mathrm{kWh} / \mathrm{m}^{2}$

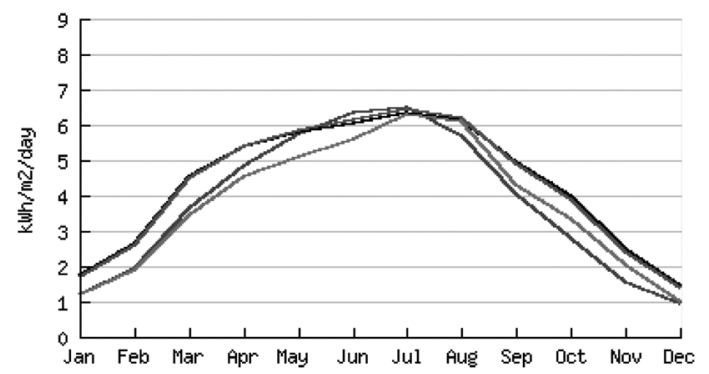

$44^{\circ} 49^{\prime} 12^{\prime \prime N o r t h, ~} 20^{\circ} 27^{\prime} 3$ "East

Figure 18. Average daily solar irradiance potential for PV modules mounted at angle of $5^{\circ}$

- Horizontal irradiation - Irradiation optimal ansle - Irradiation at $30 \mathrm{deg}$. - Direct normal irradiation 
TABLE VII: Tabular presentation of average daily solar irradiance potential for PV modules mounted at an angle of $30^{\circ}$ - Variant 3

\begin{tabular}{|c|c|c|c|c|c|c|c|c|c|c|}
\hline MONTH & $\mathrm{HH}$ & HOPT & $\mathrm{H}(90)$ & DNI & IOPT & $\mathrm{TL}$ & $\mathrm{D} / \mathrm{G}$ & $\mathrm{TD}$ & $\mathrm{T} 24 \mathrm{H}$ & NDD \\
\hline JAN & 1180 & 1740 & 1680 & 1220 & 60 & 2 & 0.67 & 2.2 & 0.6 & 513 \\
\hline FEB & 1930 & 2660 & 2370 & 1920 & 54 & 2.3 & 0.6 & 2.8 & 1.3 & 386 \\
\hline MAR & 3640 & 4560 & 3520 & 3430 & 44 & 2.6 & 0.52 & 9.1 & 7.1 & 302 \\
\hline APR & 4850 & 5380 & 3300 & 4530 & 30 & 3 & 0.44 & 14.9 & 12.8 & 99 \\
\hline MAY & 5770 & 5790 & 2870 & 5100 & 17 & 3.6 & 0.42 & 19.8 & 17.8 & 24 \\
\hline JUN & 6330 & 6040 & 2660 & 5610 & 11 & 3.5 & 0.4 & 23 & 21.4 & 4 \\
\hline JUL & 6500 & 6350 & 2880 & 6310 & 15 & 3.3 & 0.35 & 25.1 & 23.5 & 0 \\
\hline AUG & 5710 & 6160 & 3390 & 6090 & 26 & 3.4 & 0.33 & 25.1 & 23.1 & 11 \\
\hline SEP & 4050 & 4960 & 3560 & 4310 & 41 & 3.4 & 0.42 & 19.9 & 17.9 & 63 \\
\hline OCT & 2810 & 3990 & 3510 & 3350 & 54 & 2.7 & 0.47 & 15.2 & 13 & 243 \\
\hline NOV & 1570 & 2490 & 2470 & 2030 & 62 & 2.1 & 0.56 & 9.8 & 8 & 408 \\
\hline DEC & 963 & 1450 & 1430 & 1020 & 61 & 2 & 0.69 & 3.8 & 2.2 & 523 \\
\hline YEAR & 3790 & 4310 & 2810 & 3750 & 34 & 2.9 & 0.43 & 14.2 & 12.4 & 2576 \\
\hline
\end{tabular}

Based on these data (Table 7, Fig. 19) can draw conclusions about the solar potential for the tilt $30^{\circ}$ :

1. The average annual irradiation: $177083 \mathrm{~W} / \mathrm{m}^{2}$

2. The total annual insolation for 2009: $1551.25 \mathrm{kWh} / \mathrm{m}^{2}$

3. Direct component of the annual insolation of 2009: $868.7 \mathrm{kWh} / \mathrm{m}^{2}$

4. The diffuse component of the annual insolation for 2009: 682.55 $\mathrm{kWh} / \mathrm{m}^{2}$

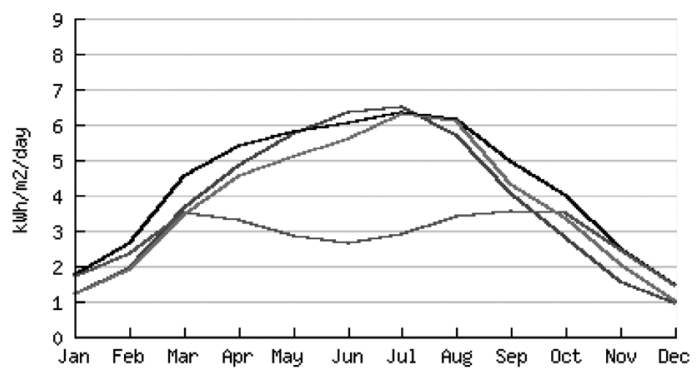

$44^{\circ} 49^{\prime} 12^{\prime \prime}$ North, $20^{\circ} 27^{\prime} 3^{\prime \prime}$ East

Figure 19. Average daily solar radiation and the potential for PRV modules mounted at angle of $30^{\circ}$ 
The data were used from meteorological stations throughout Europe which are located in the database of PVGIS. The way he calculates potential is briefly described previously. The total annual insolation obtained on that occasion is:

1. For the angle $0^{\circ}: 1361.45 \mathrm{kWh} / \mathrm{m}^{2}$

2. For the angle of $5^{\circ}: 1408.9 \mathrm{kWh} / \mathrm{m}^{2}$

3. For the angle of $30^{\circ}: 1551.25 \mathrm{kWh} / \mathrm{m} \underline{2}$

For the purpose of this research was used Polycristalin PV module dimensions of $165 \mathrm{x} 99 \mathrm{~cm}$ total area of $1.63 \mathrm{~m}^{2}$. The new supply system is designed to meet the demand for electricity during the summer months almost completely from the PV panels. According to a very unequal loads that occur during the year, the proposed system should be flexible, to enable greater consumption of electricity in those days when it is necessary. During those summer months, PV supply is sufficient to cover the entire consumption of electricity in the Belgrade fortress area.

According to the analysis of the required number of PV modules for uninterrupted operation of public lighting in the Belgrade fortress in the software program PVsyst V6.47 following results were obtained:

\section{Variant 1:}

Photovoltaic modules, with a total surface area of $3524.1 \mathrm{~m}^{2}$, i.e. 2162 panels, with a total installed power of $529 \mathrm{~kW}$ produces electricity from monthly min $13372 \mathrm{kWh}$ in December to the max $88540 \mathrm{kWh}$ in July. Total production of electricity at the annual level in the variant 1 is $588,991 \mathrm{kWh}$. The required quantity of electricity for the lighting of the Belgrade fortress is 611324.66 $\mathrm{kWh}$. This variant does not meet the demand for electricity for lighting the complete Belgrade Fortress area (Fig. 20).
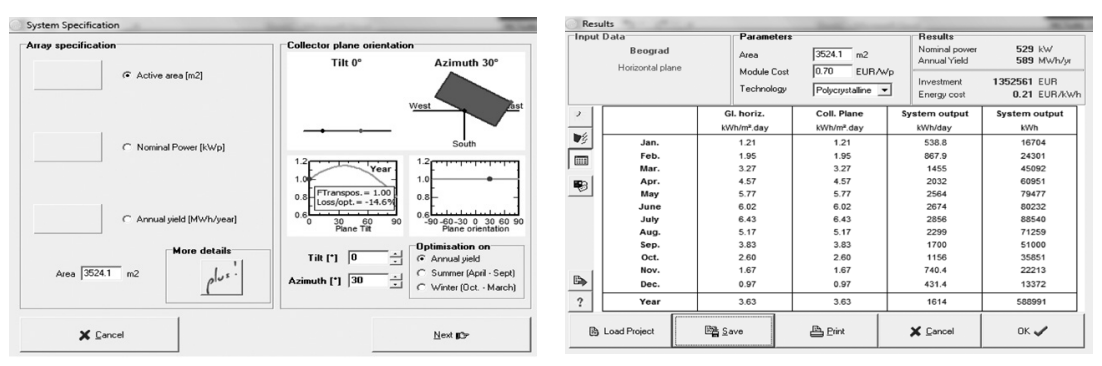

Figure 20. Calculation in PVsyst V6.47 Variant 1 
Variant 2:

Photovoltaic modules, with a total surface area of $3524.1 \mathrm{~m}^{2}$, i.e. 2162 panels, with a total installed power of $529 \mathrm{~kW}$ produces monthly electricity of at least $14,933 \mathrm{kWh}$ in December to the max $89690 \mathrm{kWh}$ in July. Total production of electricity at the annual level in the variant 2 is $611,287 \mathrm{kWh}$. The required quantity of electricity for the lighting of the Belgrade fortress area is 611324.66 $\mathrm{kWh}$. This variant does not meet the demand for electricity for lighting the complete Belgrade Fortress area (Fig. 21).
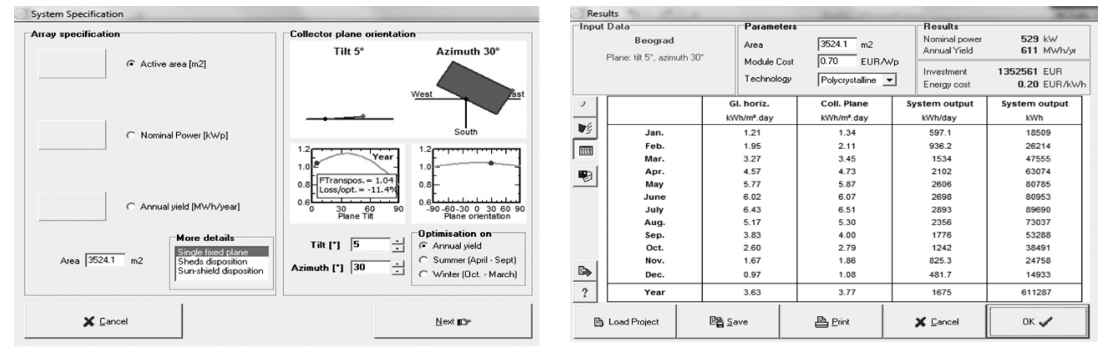

Figure 21. Calculation in PVsyst V6.47 Variant 2

Variant 3:

Photovoltaic modules, with a total surface area of $3524.1 \mathrm{~m}^{2}$, that is 2162 panels, with a total installed power of $529 \mathrm{~kW}$ produces a monthly electricity from min $21418 \mathrm{kWh}$ in December to the max $88660 \mathrm{kWh}$ in July. Total production of electricity at the annual level in the variant 3 is $673,621 \mathrm{kWh}$. The required quantity of electricity for the lighting of the Belgrade fortress area is 611324.66 $\mathrm{kWh}$. This variant meets the demand for electricity for lighting the complete Belgrade Fortress area (Fig. 22).
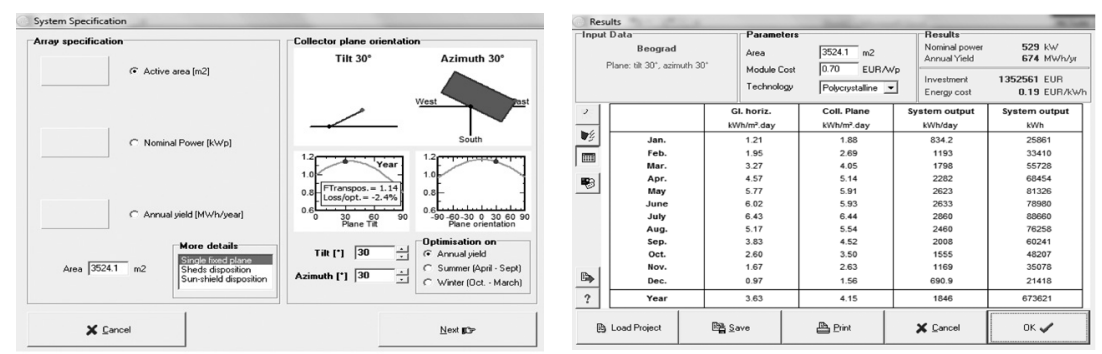

Figure 22. Calculation in PVsyst V6.47 Variant 3 
TABLE VI I : Comparative review of monthly and annual production of electricity for different variants of PV modules

\begin{tabular}{cccc}
\hline & VAR. 1 & VAR. 2 & VAR. 3 \\
\hline 1 & 16704 & 18509 & 25861 \\
2 & 24301 & 26214 & 33410 \\
3 & 45092 & 47555 & 55728 \\
4 & 60951 & 63074 & 68454 \\
5 & 79477 & 80785 & 81326 \\
6 & 80232 & 80953 & 78980 \\
7 & 88540 & 89690 & 88660 \\
8 & 71259 & 73037 & 76258 \\
9 & 51000 & 53288 & 60241 \\
10 & 35851 & 38491 & 48207 \\
11 & 22213 & 24758 & 35078 \\
12 & 13372 & 14933 & 21418 \\
\hline TOTAL & 588991 & 611287 & 673621 \\
\hline
\end{tabular}

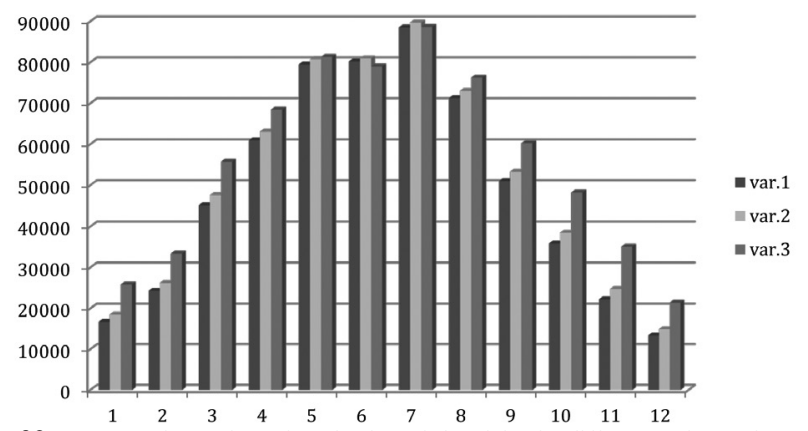

Figure 23. Comparative review of production of electricity for different variants of PV modules

\section{CONCLUSION}

The contribution of renewable energy for production of electricity through the PV module is assessed through a comparative analysis of the proposed integration of PV modules (Table 8, Fig. 23). On an annual basis, integrated photovoltaic modules can produce electricity from min $588991 \mathrm{kWh}$ (Variant 1) to max $673,621 \mathrm{kWh}$ (Variant 3). The analyzed solutions can meet the total annual demand for electricity of the complete Belgrade fortress area under protection. It is noticeable a significant difference in the amount of electricity generated by variants. It can be concluded that PV modules which set administratively and non-transparently modules can generate the most electricity. It is necessary in further research to analyze the combination of certain basic variants in order to meet shaped and visual aspects of application of PV modules in protected cultural-historical wholes. Adequate orientation and position of PV modules, can contribute to greater energy efficiency of PV modules. 
The analysis concluded that the installation of PV systems within an area under protection such as Belgrade fortress contributed to the improvement of the ecological quality of analyzed locations. The benefit of the hybrid solution is to reduce costs for construction and maintenance of the necessary infrastructure for lighting by using the conventional energy sources.

The proposed solution of the system for power generation (Fig. 25), aimed for the public lighting of the Belgrade fortress, hypothetically set on the roof of the Beton Hall at Sava pier, where today is a public parking, which does not impair views and architectural value of the historic environment, is optimal in terms of the fulfillment of the following parameters:

- That the installed capacity of consumers of electrical generation is $150 \mathrm{~kW}$ under normal operating conditions.

- The increase in installed capacity would influence on the increase of the number and surface area of required of PV modules.

- Estimated maximum daily consumption for one month from $68888.11 \mathrm{kWh}$.

- The projected life of the system is 25 years.

This study was not intended to present an economic analysis and justification of the use of PV modules in the Belgrade fortress. The use of PV modules would provide a reduction in $\mathrm{CO}_{2}$ emissions $514.72 \mathrm{t}$ at the annual level and in this way would significantly reduce the environmental pollution for a given location. Maintenance of the system would be minimal. When it comes to solar systems, are observed positive reviews regarding the construction of such systems. Integrated systems of PV modules (Figure 26, 27) raise people's awareness of renewable energy and environmental protection and in this way further contributing to the development of environmental awareness in the local community.

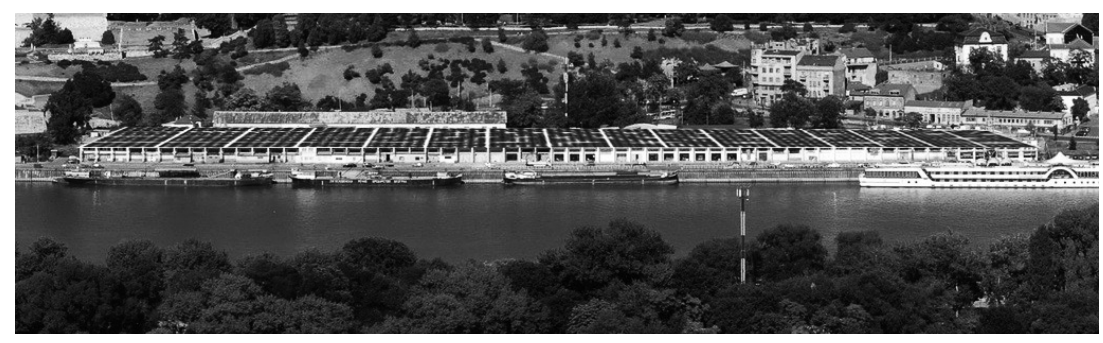

Figure 25. Applications of PV modules under the Cultural Monuments the Belgrade Fortress
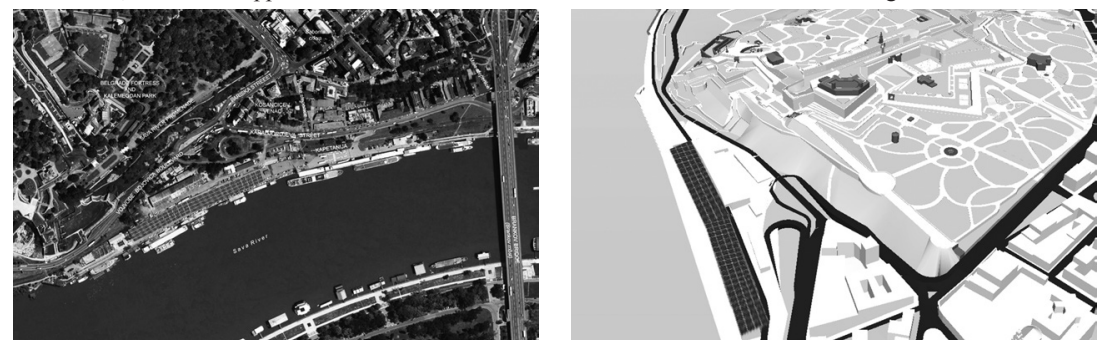
3., Николић, В.,Шиљкут, П., Петровић, Energy efficient power supply of autonomous consumers using hybrid (photovoltaic and diesel aggregates) sources

G., Hille, and K., Reiche, "Potential der Photovoltaik auf ärmschutzwänden an deutschen Verkehrswegen.” 11. Symposium Photovoltaische Solarenergie. Staffelstein, Germany, 1996.

https://content.historicengland.org.uk/images-books/publications/microgeneration-in-thehistoric-environment/microgeneration.pdf/

C., Ненадовић, Заштита градитељског наслеђа (Београд: Универзитет у Београду, Архитектонски факултет, 1980).

J., Несковић, Ревитализација споменика културе (Београд: Универзитет у Београду, Архитектонски факултет, 1986).

М., Поповић, Београдска тврђава (Београд: ЈП Београдска тврђава, 2006).

М., Нешковић, “'Заштита и ревитализација београдске тврђаве као историјског језгра града" (докторска дисертација, Универзитет у Београду, Архитектонски факултет, 2015).

М., Поповић, Београдска тврђава (Београд: ЈП Београдска тврђава, 2006).

Mirjana Roter-Blagojević, "The modernization and urban transformation of the Belgrade in the 19th and early 20th century," in Planing Capital Cities: Belgrade, Bucurest, Sofia, eds. Doytchinov, G., Đukić, A., Catalina, I. (Verlag der Technischen Universität Graz, 2015), 20-42.

http://beogradskonasledje.rs/kd/zavod/stari_grad/beogradska_tvrdjava.html

Jones, C.J.C. and Thompson, D.J. 1999. Application of Numerical Models to a System of Trainand Track-Mounted Acoustic Shields. In Sixth International Congress on Sound and Vibration, pp. 2661-2668.

М., Јовановић, Музеологија и заштита споменика културе (Београд: Универзитет у Београду, Филозофски факултет факултет, 1994).

K., Johannsen, and. M., Möser, ''The Influence of the Sur- face of Small Barriers on the Sound Reduction Efficiency of Shroud-Barrier Combinations," In Seventh International Congress on Sound and Vibration, 2623-2630, 2000.

Ibid.

Р., Топић, Обновљиви $u$ секундарни ресурси (Београд: Универзитет у Београду, Машински факултет, 2013).

Т., Павловић, Соларна енергетика (Ниш: Филозофски факултет Ниш, 1994).

Николић, 3., Шиљкут, В., Петровић, П. Energy efficient power supply of autonomous consumers using hybrid (photovoltaic and diesel aggregates) sources

Aleksandra Krstic-Furundzic, '’PV Integration in Design of New and Refurbishment of Existing Buildings: Educational Aspect," JAAUBAS-Journal of the Association of Arab Universities for Basic and Applied Sciences, Volume 4 (Supplement) (2007): 135-146. В., Ристић, Управљање јавним осветљењем на територији града Београда (Београд: ЈКП Јавно осветљење). 
Hille, G. and Reiche, K. 'Potential der Photovoltaik auf Lärmschutzwänden an deutschen Verkehrswegen.” 11. Symposium Photovoltaische Solarenergie. Staffelstein, Germany, 1996.

Jones, C.J.C. and Thompson, D.J. "Application of Numerical Models to a System of Trainand Track-Mounted Acoustic Shields." In Sixth International Congress on Sound and Vibration,2661-2668, 1999.

Möser, M. and Volz., R. 'Improvement of Sound Barriers using Headpieces with Finite Impedance.” JASA 106 (1999): 3049-3060.

Johannsen, K. and Möser. M. 'The Influence of the Sur- face of Small Barriers on the Sound Reduction Efficiency of Shroud-Barrier Combinations." In Seventh International Congress on Sound and Vibration, 2623-2630, 2000.

Krstic-Furundzic, A. 'PV Integration in Design of New and Refurbishment of Existing Buildings: Educational Aspect." JAAUBAS-Journal of the Association of Arab Universities for Basic and Applied Sciences, Volume 4 (Supplement) (2007): 135-146.

Јовановић, М.. Музеологија и заштита споменика културе. Београд: Универзитет у Београду, Филозофски факултет факултет, 1994.

Несковић, Ј.. Ревитализација споменика културе. Београд: Универзитет у Београду, Архитектонски факултет, 1986.

Нешковић, М. “'Заштита и ревитализација београдске тврђаве као историјског језгра града.” докторска дисертација, Универзитет у Београду, Архитектонски факултет, Београд, 2015.

Ненадовић, С.. Заштита градитељског наслеђа. Београд: Универзитет у Београду, Архитектонски факултет, 1980.

Николић, 3., Шиљкут, В., Петровић, П. Energy efficient power supply of autonomous consumers using hybrid (photovoltaic and diesel aggregates) sources

Поповић, М. Београдска тврђава. Београд: ЈП Београдска тврђава, 2006.

Павловић, Т. Соларна енергетика. Ниш: Филозофски факултет Ниш, 1994.

Ристић, В. Управљање јавним осветљењем на територији града Београда. Београд: ЈКП Јавно осветљење.

Roter-Blagojević, Mirjana. "The modernization and urban transformation of the Belgrade in the 19th and early 20th century." In Planing Capital Cities: Belgrade, Bucurest, Sofia, edited by Doytchinov, G., Đukić, A., Catalina, I., 20-42. Verlag der Technischen Universität Graz, 2015.

Топић, Р. Обновљиви $и$ секундарни ресурси. Београд: Универзитет у Београду, Машински факултет, 2013.

http://beogradskonasledje.rs/kd/zavod/stari_grad/beogradska_tvrdjava.html 10

http://www.buildingconservation.com/articles/church-solar/church-solar.htm

http://eandt.theiet.org/magazine/2012/03/retrofitting-heritage-buildings.cfm

https://content.historicengland.org.uk/images-books/publications/microgeneration-in-thehistoric-environment/microgeneration.pdf/

http://www.beoassistant.com

http://www.solaripedia.com

http://www.parcerisa.cat

http://beobuild.rs 